assesses the probability of serious infection (i.e. leading to hospitalization) in SLE patients and to test it in an independent cohort.

Methods: The SCORE was developed using data from the RELESSER (Spanish Society of Rheumatology Lupus Registry) cohort of 3658 SLE patients. A Cox regression model for repeated events (Andersen-Gill) was applied to assess which demographic and clinical factors were independently associated with increased risk of developing serious infection (Table 1). The SCORE was then validated using retrospective data from the UCLH (University College London Hospital) cohort including 699 SLE patients. Median SCORE values were compared between sub-groups of patients using the U-Mann-Whitney test.

Results: Among 699 SLE UCLH patients, 98 (14\%) developed serious infection. We compared these patients with 111 SLE controls who have never suffered serious infection. The characteristics of both groups are summarized in table 2. The infection group were more likely to have suffered previous infection $(P=0.001)$ and/or hospitalized for SLE $(P<0.001)$ and had renal and joint disease $(P=0.005)$. Over a quarter of the infection group died from their infection. Median (Md) SCORE at diagnosis in SLE patients with infection was 4.27 (IQR 3.18) which was significantly higher than in the control group (Md 2.55, IQR 3.79) $(z=3.341$; $\mathrm{P}=0.0008$ ). Md SCORE before infection in patients was 5.3 (IQR 3.68) which was significantly higher than SCORE at diagnosis $(\mathrm{Z}=-5.733 ; \mathrm{P} \leq 0.001)$ in those patients. By ROC analysis, we defined three possible cut-offs to distinguish patients with and without infection. The area under the ROC curve was $0.66(\mathrm{Cl}$ $95 \% 0.56$ to 0.71 ). A cut-off for SCORE at diagnosis $>3.18$ identified patients who would develop serious infection with sensitivity (S) $76.5 \%$ and specificity (SPC) $50.5 \%$. For SCORE $>3.79$, S was $64.3 \%$ and SPC $57.7 \%$. For SCORE $>4.24$, S was $64.3 \%$ and SPC $60.4 \%$.

TABLE 1 - FACTORS INCLUDED IN THE "SCORE"

\begin{tabular}{|l|l|l|l|}
\hline Risk factor & B & P-value & HR \\
\hline $\begin{array}{l}\text { Age at diagnosis } \\
\text { (>46 years old) }\end{array}$ & 0.1163 & 0.001 & 1.12 \\
\hline $\begin{array}{l}\text { Latin American } \\
\text { ethnicity }\end{array}$ & 0.427 & 0.001 & 2.40 \\
\hline $\begin{array}{l}\text { Corticosteroids } \\
\text { (>10 mg/day) at } \\
\text { time of } \\
\text { calculating SCORE }\end{array}$ & 0.2878 & 0.001 & 1.33 \\
\hline Sex=male & 0.3692 & 0.0001 & 1.49 \\
\hline $\begin{array}{l}\text { Previous } \\
\text { hospitalization } \\
\text { (for SLE) }\end{array}$ & 1.0049 & $<0.00001$ & 2.73 \\
\hline Katz index & 0,062 & 0.002 & 1.06 \\
\hline $\begin{array}{l}\text { Prior infection at } \\
\text { any time }\end{array}$ & 0.8739 & $<0.0001$ & 2.40 \\
\hline
\end{tabular}

Table 2

\begin{tabular}{|c|c|c|c|}
\hline & SLE-infection $(n=98)$ & SLE-non infection $(n=111)$ & $P$ value \\
\hline Gender & $\begin{array}{l}\text { Females: } 90(91.8) \\
\text { Males: } 8(8.2 \%)\end{array}$ & $\begin{array}{l}\text { Females: } 103(92.8 \%) \\
\text { Males: } 8(7.2 \%)\end{array}$ & ns \\
\hline $\begin{array}{l}\text { Mean age (diagnosis } \\
\text { of SLE) }\end{array}$ & 30.5 & 31 (18) & ns \\
\hline Ethnicity & $\begin{array}{c}\text { Caucasian } 48(49 \%) \\
\text { Latin American } 3(3.06 \%) \\
\text { African/Caribbean } 28(28.6 \%)\end{array}$ & $\begin{array}{c}\text { Caucasian } 72(64.9 \%) \\
\text { Latin American } 2(1.8 \%) \\
\text { African/Caribbean } 20(18.02 \%)\end{array}$ & \\
\hline & $\begin{array}{l}\text { Asian } 7(7.1 \%) \\
\text { Other } 12(12.2 \%)\end{array}$ & $\begin{array}{l}\text { Asian } 6(5.4 \%) \\
\text { Other } 12(10.8 \%)\end{array}$ & ns \\
\hline $\begin{array}{l}\text { Median length of } \\
\text { follow-up (IQR) }\end{array}$ & 9 & & 0.001 \\
\hline Previous treatment & $\begin{array}{l}\text { Steroids (at any time) } 89(90.8 \%) \\
\text { MMF } 25(25.5 \%) \\
\text { AZA } 46(47 \%) \\
\text { Cyclophosphamide } 20(20.4 \%) \\
\text { Biological treatment } 24(24.5 \%)\end{array}$ & $\begin{array}{l}\text { Steroids (at any time) } 61(55 \%) \\
\text { MMF } 23(20.7 \%) \\
\text { AZA } 29(26.1 \%) \\
\text { Cyclophosphamide } 13(11.7 \%) \\
\text { Biological treatment } 22(19.8 \%)\end{array}$ & $\begin{array}{c}<0.001 \\
\text { ns } \\
<0.001 \\
0.01 \\
n s\end{array}$ \\
\hline $\begin{array}{l}\text { Patients with }>1 \\
\text { Infection }\end{array}$ & 18 (18.4\%) & & \\
\hline
\end{tabular}

Conclusions: We have developed a SCORE for predicting risk of serious infection in SLE and validated it in an independent cohort. Given the potential mortality from such infections, this SCORE could be clinically useful though the moderate sensitivity and specificity necessitate caution and further prospective studies. Disclosure of Interest: None declared

DOI: 10.1136/annrheumdis-2017-eular.4130

\section{THU0257 ENHANCED ACTIVATION OF NLRP3 INFLAMMASOMES IN PATIENTS WITH SJÖGREN'S SYNDROME}

J.N. Kim, S.-K. Kim, J.-Y. Choe. Division of Rheumatology, Department of Internal Medicine, Catholic University of Daegu School of Medicine, Daegu, Korea, Republic Of

Background: There has been data about pathogenic role of NLRP3 inflammasome in Sjögren's syndrome. However, linkage between their clinical features and NLRP3 inflammasome has not been clearly defined.
Objectives: The aim of this study is to identify the association of NLRP3 inflammasome with clinical features in patients with primary Sjögren's syndrome. Methods: A total 25 female patients with Sjögren's syndrome and gendermatched 25 healthy controls were consecutively enrolled. The mRNA expression for target genes including NLRP3, ASC, caspase-1, IL-1b, and IL-18 in peripheral blood mononuclear cells (PBMCs) were measured using real-time polymerase chain reaction. Serum IL-1b and IL-18 expression were also measured by ELISA method. Clinical information and disease activity and damage for Sjogren's syndrome such as EULAR Sjögren's Syndrome Disease Activity Index (ESSDAI) and Sjögren's Syndrome Disease Damage Index (SSDDI) were collected at the time of enrollment. Statistical analysis were applied including Spearman's correlation coefficient and Mann-Whitney t-test.

Results: Patients with Sjögren's syndrome was found to be highly expressed in mRNA IL-1b and its protein, compared to controls $(p<0.001$ and $p=0.001$, respectively). The mRNA levels of caspase-1 and ASC were significantly higher than those in controls $(p=0.021$ and $p=0.008$, respectively), but not mRNA level of NLRP3. The mRNA level of IL- $1 \mathrm{~b}$ is closely related with mRNA level of NLRP3 and ESR ( $r=0.549, p<0.001$ and $r=0.577, p=0.003$, respectively). Serum IL-1b protein expression in Sjögren's syndrome was found to be associated with mRNA level of caspase-1. Based on SSDDI, patients with SSDDI $\geq 1$ was older and higher IL-1b and NLRP3 mRNA expression, compared to those with SSDDI $=0$ $(p=0.035, p=0.005$, and $p=0.016$, respectively).

Conclusions: This study confirmed that activation of NLRP3 inflammasome might implicated the pathogenesis of Sjögren's syndrome.

Disclosure of Interest: None declared

DOI: 10.1136/annrheumdis-2017-eular.3068

\section{THU0258 SERUM PARAOXONASE 3 LEVELS ARE DECREASED AND PARAOXONASE 3 ACTIVITY IS REDUCED IN PATIENTS WITH SYSTEMIC LUPUS ERYTHEMATOSUS AS COMPARED TO HEALTHY CONTROLS}

A. Dhooria ${ }^{1}$, K. Priyanka ${ }^{2}$, A. Sharma ${ }^{1}$, I. Verma ${ }^{2}$, A. Lal ${ }^{3}$, S. Singh ${ }^{1} .{ }^{1}$ Internal Medicine; ${ }^{2}$ Biochemistry; ${ }^{3}$ Radiodiagnosis, PGIMER, Chandigarh, India

Background: Premature atherosclerosis is a well recognised comorbidity in patients with SLE (1). Elevated levels of circulating Oxidised Low Density Lipoprotein (OxLDL) have been described in SLE patients, especially in those with a history of cardiovascular disease (2). Paraoxonase 3 (PON 3 ) is believed to play a role in prevention of atherosclerosis by contributing towards the anti oxidant actions of high density lipoprotein (HDL).

Objectives: To determine serum PON3 levels and PON 3 activity in patients with SLE and compare them with healthy controls.

Methods: Serum PON 3 levels and PON3 activity were determined in 100 patients of SLE with no prior history of coronary artery disease and they were compared with those of 50 healthy controls who did not have diabetes, hypertension or coronary artery disease. Serum PON3 concentration was determined by enzyme-linked immunosorbent assay (ELISA) using anti-PON3 antibody specific for human PON3. PON 3 activity was estimated using Spectrophotometric assay which quantified the hydrolysis of dihydrocoumarin at $270 \mathrm{~nm}(3)$.

Results: PON 3 levels were lower in SLE patients $(P<0.001)$ and PON 3 activity was reduced $(p<0.001)$ as compared to healthy controls. In subgroup analysis of SLE patients, PON 3 activity and levels did not correlate with disease activity. On Univariate analysis, serum creatinine $\left(r^{2}=0.06, p<0.002\right)$, age $\left(r^{2}=0.03\right.$, $\mathrm{p}=0.035)$, and SLE status $\left(r^{2}=0.27, p<0.001\right)$ contributed to PON3 levels. On Univariate analysis, serum creatinine $\left(r^{2}=0.15, p<0.001\right)$, AST $\left(r^{2}=0.04, p=0.01\right)$, $\operatorname{ALT}\left(r^{2}=0.16, p<0.001\right)$ and SLE status $\left(r^{2}=0.77, p<0.001\right)$ contributed to PON3 levels. On multivariate analysis, only SLE status predicted PON 3 levels $(\mathrm{P}<0.001)$ and PON 3 activity $(\mathrm{p}<0.001)$.

\begin{tabular}{|c|c|c|c|}
\hline Parameter & SLE patients & Healthy controls & $P$ value \\
\hline Serum Creatinine (mg/dl) & $0.55(0.19)$ & $0.58(0.19)$ & $<0.001$ \\
\hline Aspartate aminotransferase $(\mathrm{U} / \mathrm{L})$ & $22(11)$ & $21(18)$ & 0.02 \\
\hline Alanine aminotransferase (U/L) & $12.45(13)$ & $26.5(15)$ & $<0.001$ \\
\hline Alkaline Phosphatase (U/L) & $70(34)$ & $63.5(49)$ & 0.408 \\
\hline Total cholesterol (mg/dl) & $155(67)$ & $168.5(25)$ & 0.076 \\
\hline Low density lipoprotein (mg/dl) & $84.5(44)$ & $102(28)$ & 0.023 \\
\hline High density lipoprotein (mg/dl) & $41(21)$ & $43(11)$ & 0.329 \\
\hline Triglyceride (mg/dl) & $136(96)$ & $129(64)$ & 0.359 \\
\hline Very low density lipoprotein (mg/dl) & $27(19)$ & $26(12)$ & 0.344 \\
\hline Paraoxonase 3 activity* & $38.43(37.64)$ & $69.54(27.80)$ & $<0.001$ \\
\hline Paraoxonase 3 levels ${ }^{\star *}$ & $0.54(0.32)$ & $2.41(1.06)$ & $<0.001$ \\
\hline
\end{tabular}

All values are in Median (Interquartile Range). ${ }^{*} \mu \mathrm{mol} \mathrm{ml}^{-1} \mathrm{~min}^{-1},{ }^{* \star} \mu \mathrm{g} \mathrm{ml}^{-1}$.

Conclusions: PON3 levels are reduced and PON 3 activity is decreased in patients with SLE as compared to healthy controls, the difference was attributable to the disease itself. This may contribute to premature atherosclerosis in these patients.

References:

[1] Nikpour M, Urowitz MB, Gladman DD. Premature atherosclerosis in systemic lupus erythematosus. Rheum Dis Clin North Am. 2005;31:329-54.

[2] Frostegard J, Svenungsson E, Wu R et al. Lipid peroxidation is enhanced in patients with systemic lupus erythematosus and is associated with arterial and renal disease manifestations. Arthritis Rheum. 2005;52:192-200. 
[3] Draganov DI, Teiber JF, Speelman A et al. Human paraoxonases (PON1, PON2, and PON3) are lactonases with overlapping and distinct substrate specificities. J Lipid Res. 2005;46:1239-47.

Acknowledgements: None.

Disclosure of Interest: None declared

DOI: 10.1136/annrheumdis-2017-eular.3459

\section{THU0259 RESPIRATORY SYMPTOMS IN PRIMARY SJÖGREN'S SYNDROME, A CROSS-SECTIONAL STUDY OF THE OASIS COHORT}

A. Dumusc ${ }^{1}$, B. Fisher ${ }^{2}$, F. Barone ${ }^{2}$, A. Richards ${ }^{3}$, A. Poveda ${ }^{3}$, J. Higham ${ }^{3}$, S. Rauz ${ }^{2}$, S. Bowman ${ }^{1} .{ }^{1}$ University Hospitals Birmingham NHS Foundation Trust; ${ }^{2}$ Institute of Inflammation and Ageing, University of Birmingham;

${ }^{3}$ Birmingham Dental Hospital, Birmingham, United Kingdom

Background: In previous studies, 5 to $35 \%$ of patients with primary Sjögren's syndrome (pSS) are reported to have respiratory symptoms (RS). Pulmonary involvement varies from a dry cough due to airway dryness to life-threatening interstitial lung disease.

Objectives: To evaluate RS prevalence in patients with pSS and compare characteristics of pSS patients with and without RS to those in patients without pSS suffering from ocular or oral dryness.

Methods: Cross-sectional study of patients at the time of their inclusion in the OASIS cohort between 2014 and September 2016. This UK prospective research cohort includes patients with suspected pSS or known pSS and aims to collect long-term high quality data with regular clinical, dental and ophthalmological assessments. We asked systematically all the patients if they had any RS. In case of clinically significant RS, pulmonary function tests (PFTs) were requested, and if needed, a high-resolution chest tomography (HRCT) was performed. We included in the analysis only patients fulfilling the AECG (2002) criteria for pSS and excluded patients with secondary Sjögren's syndrome. Characteristics of pSS patients with and without RS and non-pSS patients with sicca symptoms were compared. For statistical analysis, we used unpaired t test, Mann-Whitney test, Fisher's exact test and Chi-square test when appropriate. $\mathrm{P} \leq 0.05$ was considered statistically significant.

Results: Among the 157 patients included in the cohort, 70 fulfil the AECG criteria for pSS and 63 have sicca symptoms without pSS. In the pSS/sicca non-pSS groups, $25.7 \% / 15.9 \%$ had RS (cough $10.0 \% / 7.9 \%$ and breathlessness $15.7 \% / 6.3 \%$ ) and $5.7 \% / 1.6 \%$ an abnormal chest clinical examination respectively. PSS patients with pre-existing lung disease $(n=11)$ had significantly more RS than pSS patients without it $(n=59): 54.5 \%$ versus $20.3 \%(p=0.03)$

PSS patients with RS or abnormal chest clinical examination $(n=21)$ had a higher ESSDAl index value (mean $+S D$ ) than patients without them $(n=49)(7.8+5.7$ versus $5.0 \pm 4.9, p=0.04$ ), essentially due to a higher constitutional domain score $(1.7 \pm 2.1$ versus $0.6 \pm 1.5, p=0.01)$ and a higher respiratory domain score $(1.3 \pm 2.8$ versus $0, p<0.01$ ). They also had a higher ESSPRI index value (mean $\pm S D$ ), which is a patient reported outcome: $7.4 \pm 1.7$ versus $6.0 \pm 2.1(p=0.05)$. There were no differences between pSS patients with and without RS in terms of demographic characteristics, objective measurements of tear and saliva production, histological focus scores and auto-immunity profiles.

In this same group of pSS patients, 10 PFTs and 9 HRCTs were requested and showed abnormal results in $60.0 \%$ and $55.6 \%$ respectively. A reduced gas transfer was the most common finding in PFTs (DLCO $\mathrm{mM} / \mathrm{min} / \mathrm{kPa}$, \% predicted value, mean \pm SD: $66.7 \pm 11.7$ ). Among these patients, 2 patients were diagnosed with interstitial lung disease. Both had abnormal PFTs and HRCT.

Conclusions: One third of pSS patients presented with respiratory symptoms or abnormal chest clinical examination at inclusion in our cohort. These patients had higher ESSDAI and ESSPRI index values but did not differ in terms of objective saliva and tear production measurements and auto-antibody profile. Reduced gas transfer was the most common abnormal finding in PFTs.

Disclosure of Interest: None declared

DOI: 10.1136/annrheumdis-2017-eular.4759

\section{THU0260 LOW PLASMA CONCENTRATIONS OF APOLIPOPROTEIN M CORRELATE TO DISEASE ACTIVITY AND ENDOTHELIAL DYSFUNCTION IN SLE}

A. Bengtsson ${ }^{1}$, H. Tydén ${ }^{1}$, C. Lood ${ }^{1}$, B. Gullstrand ${ }^{1}$, B. Dahlbäck ${ }^{2}$, A. Jönsen ${ }^{1}$ ${ }^{1}$ Rheumatology, Institution of Clinical Sciences, Lund University, Lund; ${ }^{2}$ Clinical Chemistry, Institution of Translational Medicine, Malmö, Sweden

Background: ApoM is an antiatherogenic and vasculoprotective $25 \mathrm{kDa}$ apolipoprotein suggested to play a role in keeping endothelial barrier integrity. Objectives: The aims of the current study were to determine the impact of SLE disease activity on apoM levels and investigate if apoM levels reflect endothelial function in SLE.

Methods: Plasma concentrations of apoM were measured with ELISA in two SLE cohorts, all patients fulfilling $\geq 4$ American College of Rheumatology (ACR) classification criteria for SLE, and 100 healthy controls (HC). Patients in cohort I had active disease as evaluated with SLEDAI scores. In cohort II endothelial function was measured by EndoPAT 2000 and correlated to apoM levels. A low Reactive Hyperemia Index (RHI) value indicated endothelial dysfunction (ED).
Results: In cohort I, the plasma levels of apoM were found to be significantly decreased in SLE $(p<0.0001)$, and the apoM concentrations correlated inversely to disease activity (SLEDAI, $r=-0.29, p=0.0063$. ApoM was also significantly lower in patients with active nephritis, leukopenia, anti-DNA antibodies or rash compared to patients without these manifestations.

In cohort II, using linear regression analysis, there was a positive correlation between apoM levels and the RHI value, indicating endothelial dysfunction, in the younger SLE patients: $\beta=0.94 \mathrm{Cl} 95 \% 0.22,1.65 \mathrm{r}=0.32 \mathrm{p}=0.011$

Conclusions: SLE related inflammation may have an impact on lower plasma apoM, which may affect the endothelium and the process towards cardiovascular disease.

Disclosure of Interest: None declared

DOI: 10.1136/annrheumdis-2017-eular.5757

\section{THU0261 PREGNANCY COURSE AND OUTCOME IN SLE PATIENTS COMPARED TO PATIENTS WITH OTHER CONNECTIVE TISSUE AND INFLAMMATORY RHEUMATIC DISEASES - DATA FROM A PROSPECTIVE COHORT STUDY}

A. Strangfeld ${ }^{1}$, C. Bungartz ${ }^{1}$, A. Weiß ${ }^{1}$, M. Schneider ${ }^{2}$, J. Richter $^{2}$, A. Zink ${ }^{1,3}$, R. Fischer-Betz ${ }^{2} .{ }^{1}$ German Rheumatism Research Centre, Berlin; ${ }^{2}$ Department of Rheumatology \& Hiller Research Unit, University Hospital, Düsseldorf;

${ }^{3}$ Charité University Medicine, Berlin, Germany

Background: Patients with systemic lupus erythematosus (SLE) are at increased risk for pregnancy complications and adverse pregnancy outcomes. During the past decades, advances in drug treatment and management during pregnancy made successful pregnancy in patients with SLE possible. Less is known about pregnancy course in other connective tissue diseases (OCTD).

Objectives: To compare pregnancy courses and outcomes in SLE patients with those in OCTD patients and patients with other inflammatory rheumatic diseases. Methods: The German Rhekiss register is designed as nationwide, web-based longitudinal observational cohort study. Pregnant patients with confirmed diagnose of inflammatory rheumatic disease are eligible to be enrolled until the 20th week of pregnancy regardless of drug treatment. At baseline, sociodemographic parameters, prior pregnancies, comorbidities and antibody status are reported. During pregnancy, rheumatologists and patients report drug treatments, course of the maternal disease, development of fetus and complications once per trimester. After delivery, the pregnancy outcome and child development during the first two years of life are collected.

Results: Until October 2016, data of 392 patients were available and grouped according to their disease in SLE patients, those with other connective tissue disease (OCTD) and patients with all other diagnoses (allO). 121 women had already completed their pregnancy with known outcome. Of them, most patients in the OCTD group were diagnosed with undifferentiated connective tissue disease

\begin{tabular}{|c|c|c|c|}
\hline & SLE & $\begin{array}{c}\text { Other connective } \\
\text { tissue diseases }\end{array}$ & $\begin{array}{l}\text { All other } \\
\text { diagnoses }\end{array}$ \\
\hline \multicolumn{4}{|c|}{ Patient characteristics at enrolment. } \\
\hline Pregnancies, $\mathbf{n}$ & 85 & 71 & 236 \\
\hline Maternal age [vears] & $31.8(4.4)$ & $32.9(3.9)$ & $32.4(4.3)$ \\
\hline Discose duration [verrs] & $7.3(5.9)$ & $5.8(6.05)$ & $8.3(7.6)$ \\
\hline$B M I>30, n(\%)$ & $4(8.7)$ & $1(2.6)$ & $10(8)$ \\
\hline $\begin{array}{l}\text { Disease activity (physician global) } \\
{[0-10] \text { in the first trimester }}\end{array}$ & $1.5(1.3)$ & $1.7(1.5)$ & $2.6(2.2)$ \\
\hline Rheumatold factor positive, $n(\%)$ & $9(14.8)$ & $12(25.5)$ & $48(34.5)$ \\
\hline Lupus anticoagulant positive, $n$ & 6 & 1 & 1 \\
\hline Anticardiolipio antibody positive, $n$ & 13 & 3 & 1 \\
\hline Anti-B2-GP.1 positive, $n$ & 10 & 3 & 2 \\
\hline Antiphospholipidsyndrome, $n$ & 10 & 1 & 1 \\
\hline SLEDAI & $1.7(2.3)$ & 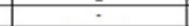 & 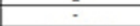 \\
\hline RAID $[0-10]$ & $1.8(1.6)$ & $1.9(2.0)$ & $2.1(2.0)$ \\
\hline \multicolumn{4}{|c|}{ Outcomes of pregnancies } \\
\hline Completed pregnancies, $\mathbf{n}$ & 32 & 25 & 64 \\
\hline Miscarriages, $\mathrm{n}$ ( $\mathrm{wk}$ of gestation) & 2 (wk 9/12), 1 elective (wk21) & $2($ wok $14 \& 21)$ & $2(w k 5 \& \& 10)$ \\
\hline \multicolumn{4}{|c|}{ No. of patients with flares during preznancy } \\
\hline $1-2$ flores & 2 & 5 & 37 \\
\hline $3-4$ flares & 0 & 0 & 10 \\
\hline $5-6$ flares & 0 & 0 & 4 \\
\hline \multirow{2}{*}{ 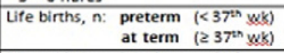 } & $5+2 \times$ twins & $2+1 \times$ twins & $7+1 \times$ twins \\
\hline & $19+3 \times$ twins & 20 & $53+1 \times$ twins \\
\hline $\begin{array}{l}\text { Mean birth weight (gtamm) of } \\
\text { singletons born ot term }\end{array}$ & 3123 & 3234 & 3477 \\
\hline $\begin{array}{l}\text { Serious complications during } \\
\text { pregnancy (n patients) }\end{array}$ & $\begin{array}{|lc|}\text { HELLP Syndrome } & (1) \\
\text { severe preeclampsis } & (1) \\
\text { serious bleedings } & (2) \\
\text { preterm lobour } & (1) \\
\text { serious infection } & (2) \\
\text { thrombotic embolism } & (1)\end{array}$ & $\begin{array}{lr}\text { HELLP Syndrome } & \text { (2) } \\
\text { preeclampsia } & \text { (2) } \\
\text { preterm rupture of } & \\
\text { membranes } & \text { (1) } \\
\text { serious infection } & \text { (1) }\end{array}$ & none \\
\hline $\begin{array}{l}\begin{array}{l}\text { Non-serious complications } \\
\text { (n patients) }\end{array} \\
\end{array}$ & $\begin{array}{|ll|}\text { gestational diabetes } & \text { (2) } \\
\text { infections } & \text { (1) } \\
\end{array}$ & $\begin{array}{|ll|}\text { Eest, diabetes } & \text { (1) } \\
\text { infections } & \text { (1) }\end{array}$ & $\begin{array}{l}\text { Eest, diabetes (3) } \\
\text { infections (4) }\end{array}$ \\
\hline $\begin{array}{l}\text { Congenital maltormation / } \\
\text { complication }\end{array}$ & $\begin{array}{l}\text { multiple anomalies } \rightarrow \\
\text { elective termination } \\
\text { polatine cleft (suspected } \\
\text { Pierre-Robin-Syndrome) } \\
\text { bamangigma at leg } \\
\text { congenital mezaureter }\end{array}$ & $\begin{array}{l}\text { sacral agenesis } \\
\text { bexadactulus, (both } \\
\text { sides) }\end{array}$ & $\begin{array}{l}\text { hip dysplasia } \\
\text { sacral } \\
\text { bămanzioma }\end{array}$ \\
\hline Postpartal maternal complications & $\begin{array}{l}\text { cerebral insult } \\
\text { serious pyelonephritis } \\
\text { hypertensive crisis }\end{array}$ & none & none \\
\hline $\begin{array}{l}\text { Neonatal complications } \\
\text { (n children) }\end{array}$ & \begin{tabular}{|ll} 
serious infections & (3) \\
lethal sepsis & (1) \\
serious ieterus & (1)
\end{tabular} & $\begin{array}{l}\text { serious infection (3) } \\
\text { serious respiratory } \\
\text { distress (3) } \\
\text { hypoglycremia (1) }\end{array}$ & $\begin{array}{l}\text { non-serious } \\
\text { infection (1) } \\
\text { serious respl- } \\
\text { ratony distress (1) }\end{array}$ \\
\hline
\end{tabular}

